(C) Romanova N.A., Romanov P.Yu., 2020, Journal of Oceanological Research, 2020, Vol. 48, No. 3, P. $96-108$

УДК 551.465

DOI: 10.29006/1564-2291.JOR-2020.48(3).6

\title{
ANTARCTIC WIND INTENSIFICATION AS INFERRED FROM THE NCEP/NCAR REANALYSIS DATA
}

\author{
Romanova N.A. ${ }^{1}$, Romanov P.Yu. ${ }^{2}$ \\ ${ }^{I}$ Shirshov Institute of Oceanology, Russian Academy of Sciences, \\ 36, Nakhimovskiy Prospekt, Moscow, 117997, Russia, \\ e-mail:romanova@ocean.ru \\ ${ }^{2}$ NOAA-CREST, City University of New York, New York, NY 10031, USA, \\ e-mail:peter.romanov@noaa.gov \\ Submitted 21.07.2020, accepted 15.10.2020.
}

\begin{abstract}
NCEP/NCAR reanalysis data have been used to examine variations of the sea level pressure and of the surface wind speed in the Antarctic region from 1950 to 2019. The objective of the work was to identify changes and quantify long-term trends in these two major weather and climate elements. The analysis included time series of monthly mean values of the sea level pressure and of the surface wind speed as well as their yearly means. The study has shown a gradual decrease of the sea level pressure and a gradual increase of the surface wind speed in the high latitude region of the Southern Hemisphere in the last 70 years (1950-2019). The largest pressure decrease was within $65-70^{\circ} \mathrm{S}$ latitude band approximately corresponding to the location of the Antarctic Circumpolar Trough (ACT). The estimated trend in the yearly averaged sea level pressure ranged from $-0.058 \mathrm{mb} / \mathrm{yr}$ over the open ocean north of ACT, within the $50-60^{\circ} \mathrm{S}$ latitude band, to $-0.148 \mathrm{mb} / \mathrm{yr}$ over the Antarctic continent, within $65-85^{\circ} \mathrm{S}$ latitudes. The zonal-mean wind speed trends ranged within $0.020 \mathrm{~m} / \mathrm{s} / \mathrm{yr}$ and $0.026 \mathrm{~m} / \mathrm{s} / \mathrm{yr}$ over the continent and over the open ocean with up to the 3-4 times larger values in the coastal areas of East Antarctica. Seasonally larger changes in both parameters occurred in the cold period of the year from April to August. Trends in both the sea level pressure and in the wind speed in the Antarctic region were found to generally decelerate in the last decade covered by the dataset.
\end{abstract}

Keywords: Reanalysis, Antarctic climate change, surface wind speed, sea level pressure

\section{Introduction}

Climate variation and change are known to show up most distinctly in high latitude regions of the Earth (Anisimov et al., 2007). Polar areas have a direct effect on the global climate through the meridional heat and water transfer, whereas the latter are directly related to the air pressure, surface temperature and the wind field dynamics. Although climate changes in the Antarctic region are generally smaller and tend to occur slower than in the Arctic (Walsh, 2009; Turner and Overland, 2009), they are still noticeable and attract a considerable research attention. These changes have been explored using a variety of approaches, techniques and datasets. Variation and long-term trends in the surface temperature and precipitation in Antarctica were examined using in situ data and satellite 
observations (Comiso, 2000; Genthon et al., 2018). Gradual warming of West Antarctica at the rate of about $0.12^{\circ} \mathrm{C}$ per decade was established using remote sensing data (Steig et al., 2009). Satellite observations have been actively used to monitor changes in the sea ice properties and dynamics (Turner et al., 2016). The amount and distribution of Antarctic icebergs and their links to changing climate have been established by Romanov et al., (2008) who collected and processed historical interactive iceberg observations from ships travelling in the Southern Ocean.

Given sparse conventional and ship-based observations of major weather and climate elements in high latitudes of the Southern Hemisphere, reanalysis datasets present an attractive source of information for studying climate variability. In the past application of these datasets in Antarctica helped to characterize the seasonal patterns and the long-term variation in the surface temperature, vertical structure of the troposphere, geopotential, sea level pressure, winds, precipitation (e.g., Wang et al., 2016; Nygard et al., 2016). Continuous updates of the reanalysis datasets stimulate their routine reassessment to establish a more reliable and accurate characterization of the Antarctic climate variability and trends. In this study we focus on the sea level pressure and on the surface wind speed. Using reanalysis data we examine their variations in the Antarctic region over the last 70 years. The primary objective of the work was to identify changes and quantify long-term trends in these two major weather and climate elements with the currently most up to date data.

\section{Data}

The study is based on the NCEP/NCAR reanalysis (Kalnay et al., 1996) available from NOAA Physical Laboratory at Boulder, Colorado, USA (https://psl.noaa.gov/). In the analysis we have used monthly mean values of the sea level pressure and of the surface wind speed provided as a subset of the NCEP/NCAR reanalysis dataset. Information on both parameters is available on a latitude-longitude grid with the grid cell size of 2.5 degree and covers the time period from 1950 to 2019. Monthly mean sea level pressure and wind speed data over the 70-year long time period were used to calculate yearly mean values as well as multi-year means for the year and individual months. Time series of monthly and yearly mean pressure and wind speed were further applied to estimate long-term changes and trends in the two parameters. Although newer and apparently more advanced global reanalysis datasets are currently available, e.g., NCEP/DOE-II (Kanamitsu et al., 2002), ERA5 (Hersbach et al., 2020), MERRA-2 (Gelaro et al., 2017) compared to NCEP/NCAR they cover a much shorter time period starting mostly in the late 1970 s or early 1980 s.

\section{Results}

Figure 1 presents global maps of the yearly mean sea level pressure and of the surface wind speed which were derived by averaging the corresponding data over the 70 -year span of the dataset. The sea level pressure map clearly identifies a belt of low 
pressure in the Antarctica coastal zone known as the Antarctic Circumpolar Trough (ACT). ACT remains generally within $60-65^{\circ} \mathrm{S}$ latitudes in the Eastern Antarctica and within $65-70^{\circ} \mathrm{S}$ latitudes in the Western Antarctica. In the map of the yearly mean wind speed there is a distinct wide band of elevated values in the open ocean north of the ACT, within the $45-60^{\circ} \mathrm{S}$ latitude belt. Stronger, in excess of $10 \mathrm{~m} / \mathrm{s}$, mean winds are also found along the continental coastline in the Atlantic and Indian Ocean sectors of Antarctica (Fig. 1b).

Further analysis involving calculated long-term monthly mean sea level pressure fields revealed a small, within about 2 degree latitude, seasonal fluctuation in the position of the ACT and a yearly amplitude of the ACT mean pressure of about $7 \mathrm{mb}$. The mean ACT pressure demonstrated a distinct semiannual oscillation with the largest maximum and the deepest minimum reached correspondingly in the months of January and October and a secondary maximum and minimum reached in June and March. In the sea level pressure reanalysis data we have also identified a considerable strengthening of the
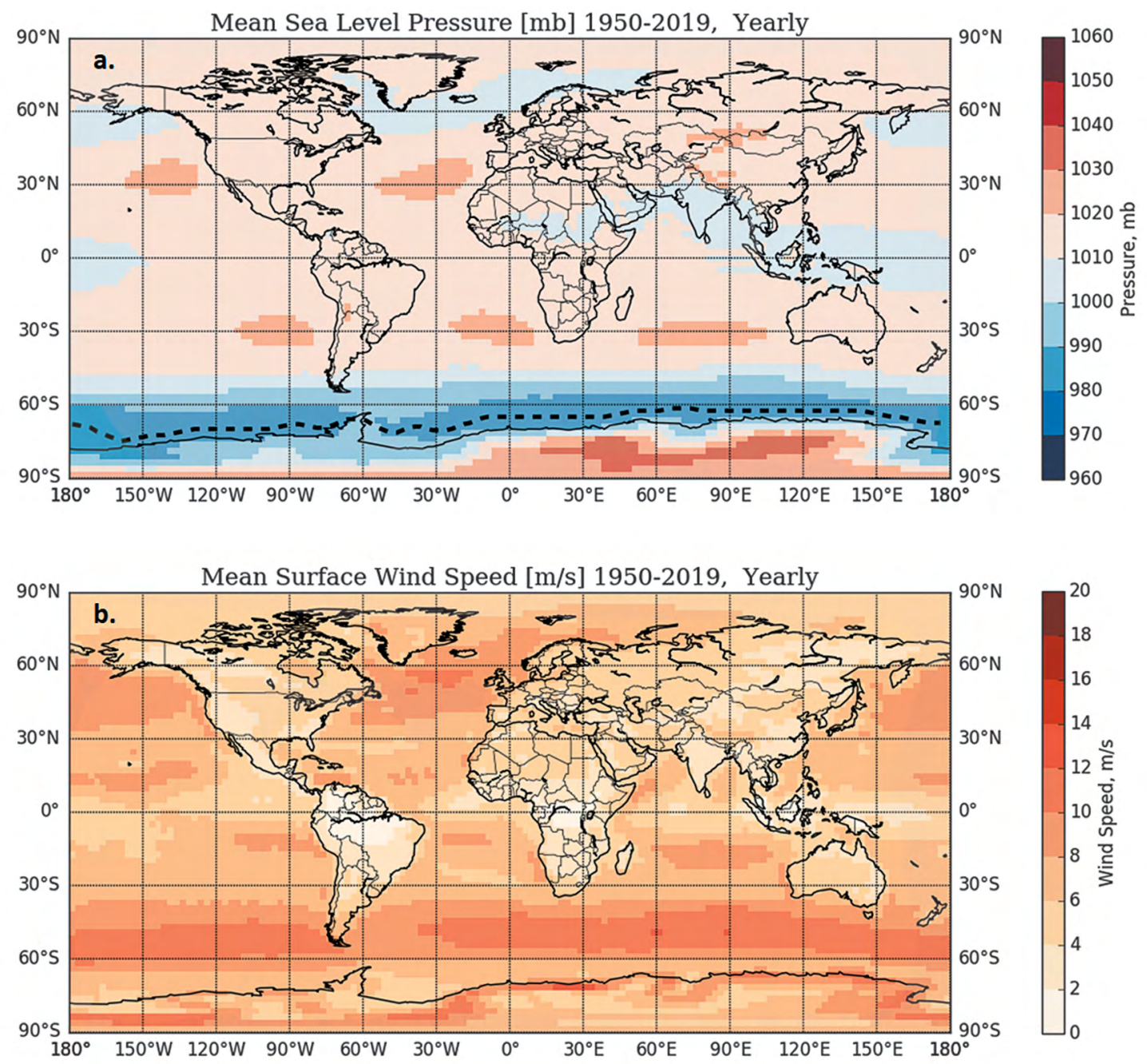

Figure 1. Yearly mean sea level pressure (a) and surface wind speed (b) averaged over 1950-2019 time period. Broken line in the mean sea level pressure map indicates the multiyear mean position of the Antarctic Circumpolar Trough (ACT). 
semi-permanent East Antarctic High in the colder period of the year, from March to September. The latter finding is consistent with the results reported by Jones and Simmonds (1994).

To assess changes in the sea level pressure and wind fields in the course of the last seven decades we split the dataset in two equal parts of 35 years long and compared the two parameters averaged over these time periods. The difference in the sea level pressure and in the wind speed averaged over 1950-1984 and over 19852019 time periods is presented in Figure 2. The principal feature seen in Figure 2a, that shows the change in the sea level pressure, is a strong deepening of the Antarctic Circumpolar Trough. The largest pressure drop of 4-8 mb occurred in the Amundsen Sea corresponding to the location of the Amundsen Sea Low, and in the Indian sector of the Southern Ocean. As seen from Figure 2a, in the Indian Ocean sector of Antarctica, the area of decreasing sea level pressure extends far beyond the coastal region deep into the continent.
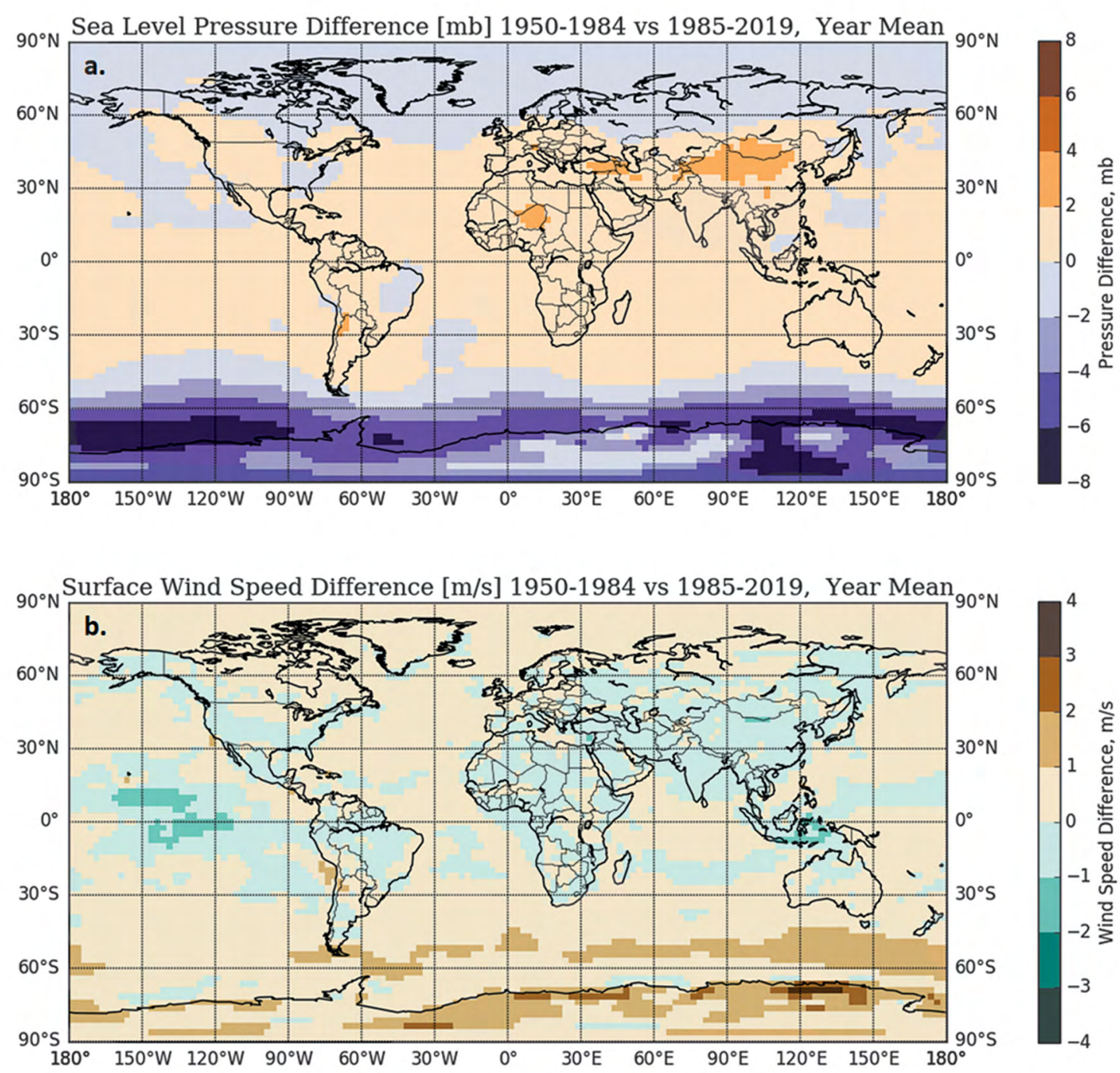

Figure 2. Change of the yearly mean sea level pressure (a) and surface wind speed (b) from 1950-1984 to 1985-2019. 
Changes in the wind speed in the high latitude region of the Southern Hemisphere from 1950-1984 to 1985-2019 were mostly positive, indicating an overall strengthening of the winds. Larger increase corresponds to the area north and south of the ACT whereas there was little to no long-term change in the wind speed at the immediate location of the ACT (Fig. 2b). The largest strengthening of the winds in the excess of $2 \mathrm{~m} / \mathrm{s}$ occurred in coastal areas of Eastern Antarctica. Surprisingly, NCEP/NCAR reanalysis data did not indicate a noticeable strengthening of the offshore winds in the Amundsen Sea, within $100-150^{\circ} \mathrm{W}$, despite an obvious deepening of the Amundsen Sea Low.

Quantitative assessment of the trends in the sea level pressure and in the surface wind speed was performed using the values of the two parameters averaged within three latitude bands of $25-35^{\circ} \mathrm{S}, 50-60^{\circ} \mathrm{S}$ and $65-85^{\circ} \mathrm{S}$. The first band incorporates the area associated with three subtropical anticyclones, the South Atlantic, the Indian and the South Pacific. These anticyclones are clearly seen in Figure 1a as areas of elevated sea level pressure. Reanalysis data records over continents were excluded from calculations of zonal mean values in this subtropical zone to characterize the sea level pressure and the surface wind speed solely over the open ocean. The second latitude zone incorporated the high latitude open ocean north of the ACT whereas the third zone represented the Antarctic continent and included the ACT.

Consistent with the results presented in Figure 2, time series of the yearly mean surface pressure and of the surface wind speed did not show any noticeable trends in the tropical open ocean areas of the Southern Hemisphere (see Figure 3). In the same time polar areas demonstrated an obvious gradual decrease of the sea level pressure and a gradual increase of the wind speed with time over the last seven decades. As follows from Figure 3, the decreasing trend in the sea level pressure over the continental Antarctica, within $65-85^{\circ} \mathrm{S}$ latitude belt, was about 2.5 times stronger than the corresponding trend over the open ocean, within $50-60^{\circ} \mathrm{S}$ latitudes, amounting correspondingly to $-0.148 \mathrm{mb} / \mathrm{yr}$ and $-0.058 \mathrm{mb} / \mathrm{yr}$. On the opposite, a somewhat larger increase in the wind speed over time, $0.026 \mathrm{~m} / \mathrm{s} / \mathrm{yr}$ vs $0.020 \mathrm{~m} / \mathrm{s} / \mathrm{yr}$, was inherent to the open ocean as compared to the continental Antarctica. All trends in the zonally-averaged sea level pressure and surface wind speed in the polar areas were statistically significant at $95 \%$ confidence level. Several individual locations in the coastal areas of East Antarctica where the long-term strengthening of the winds was most pronounced, demonstrated much larger trends reaching $0.9-1.0 \mathrm{~m} / \mathrm{s} / \mathrm{yr}$.

A more detailed seasonal analysis has shown that the decreasing trend in the sea level pressure remains stronger over the Antarctic continent than over the open ocean in all months of the year with the largest change corresponding to the April to August time period (see Figure 4). No distinct seasonal pattern was found in the wind speed trend over the Antarctic continent, within the 65 to $85^{\circ} \mathrm{S}$ latitude band, whereas the open ocean data indicated a slight strengthening of winds in austral summer and in early fall (December to April). The results suggest a somewhat larger strengthening of the winds over the open ocean than over the continent in the first half of the year whereas in the rest of the year the magnitude of the two trends was close. 

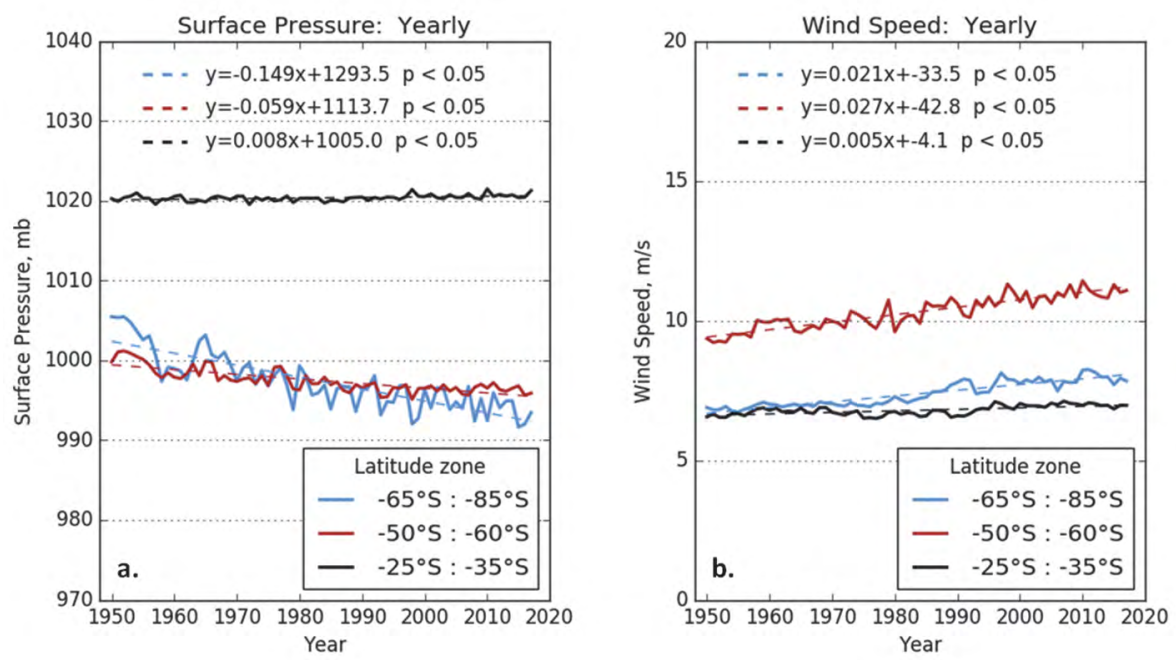

Figure 3. Time series of the yearly mean sea level pressure (a) and of the surface wind speed (b) in three latitude zones of the Southern Hemisphere derived from NCEP/NCAR reanalysis dataset.
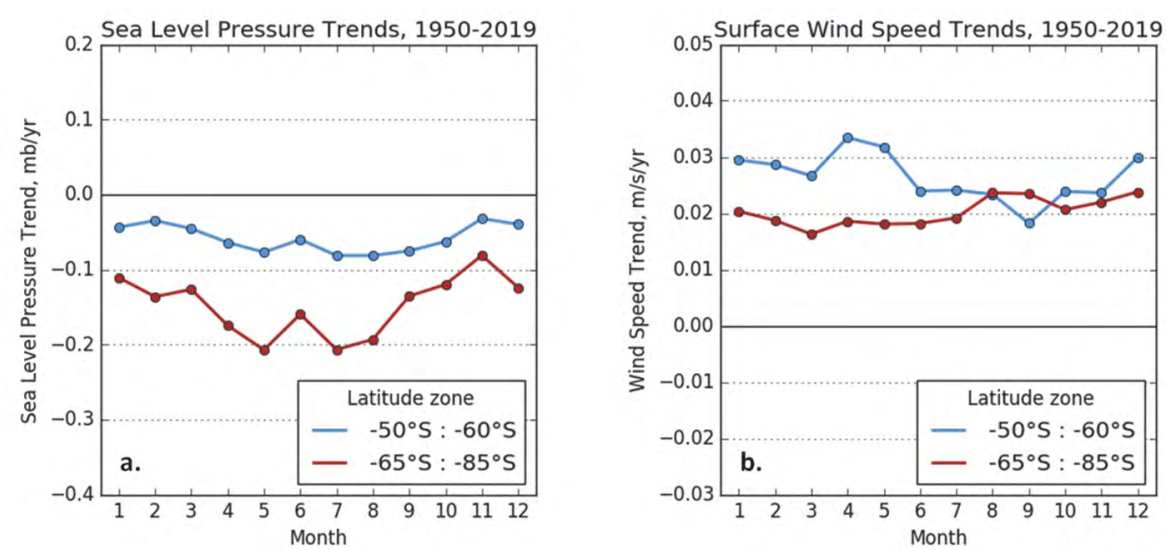

Figure 4. Trends by month of the year in the zonally-averaged sea level pressure (a) and surface wind speed (b) derived from NCEP/NCAR reanalysis dataset. Latitude zones of 50$60^{\circ} \mathrm{S}$ and $65-85^{\circ} \mathrm{S}$ correspond to the open ocean and to the Antarctic continent, respectively.

All estimated trends are statistically significant at 95\% confidence level.

To understand whether the existing trends in the sea level pressure and in the surface wind speed have been changing in recent years we compared trends calculated for the complete 70 -year time series of the zonally-averaged values of the two parameters and for the time series that exclude data for the years from 2010 to 2019. The difference between absolute values of the trend in the two parameters for 1950-2019 and for 1950-2009 over the open ocean was predominantly negative (see Table 1), suggesting a general deceleration of the observed trends in the last decade. Similarly to the open ocean, trends in the surface wind speed and in the sea level pressure in the last decade were found to also decelerate over the Antarctic continent. 
Table 1. Trends in the sea level pressure [mb/yr] and in the surface wind speed $[\mathrm{m} / \mathrm{s} / \mathrm{yr}]$ over the open ocean $\left(50-60^{\circ} \mathrm{S}\right)$ for the 1950-2019 and 1950-2009 time period and the difference of the trends indicating trend acceleration $(+)$, deceleration $(-)$ or no change (=) in the last ten years, from 2010 to 2019.

\begin{tabular}{|c|c|c|c|c|c|c|}
\hline \multirow{2}{*}{ Month } & \multicolumn{3}{|c|}{ Sea Level Pressure } & \multicolumn{3}{c|}{ Surface Wind Speed } \\
\cline { 2 - 7 } & $\begin{array}{c}\text { Trend } \\
(\mathrm{mb} / \mathrm{yr}) \\
1950-2009\end{array}$ & $\begin{array}{c}\text { Trend } \\
(\mathrm{mb} / \mathrm{yr}) \\
1950-2019\end{array}$ & $\begin{array}{c}\text { Accell }(+) / \\
\text { Deccell }(-) / \\
\text { NoChg }(=)\end{array}$ & $\begin{array}{c}\text { Trend } \\
(\mathrm{m} / \mathrm{s} / \mathrm{yr}) \\
1950-2009\end{array}$ & $\begin{array}{c}\text { Trend } \\
(\mathrm{m} / \mathrm{s} / \mathrm{yr}) \\
1950-2019\end{array}$ & $\begin{array}{c}\text { Accell }(+) / \\
\text { Deccell }(-) / \\
\text { NoChg }(=)\end{array}$ \\
\hline Jan. & -0.052 & -0.043 & - & 0.030 & 0.029 & - \\
\hline Feb. & -0.045 & -0.032 & - & 0.029 & 0.028 & - \\
\hline Mar. & -0.057 & -0.048 & - & 0.027 & 0.027 & - \\
\hline Apr. & -0.084 & -0.064 & - & 0.038 & 0.035 & - \\
\hline May & -0.085 & -0.078 & - & 0.034 & 0.033 & - \\
\hline Jun. & -0.064 & -0.060 & - & 0.021 & 0.024 & + \\
\hline Jul. & -0.104 & -0.081 & - & 0.023 & 0.024 & + \\
\hline Aug. & -0.113 & -0.082 & - & 0.026 & 0.024 & - \\
\hline Sep. & -0.083 & -0.065 & - & 0.018 & 0.018 & $=$ \\
\hline Oct. & -0.097 & -0.077 & - & 0.024 & 0.023 & - \\
\hline Nov. & -0.047 & -0.031 & - & 0.025 & 0.023 & - \\
\hline Dec. & -0.040 & -0.039 & - & 0.031 & 0.029 & - \\
\hline
\end{tabular}

\section{Discussion}

Atmospheric reanalyses schemes differ by physical parameterizations, assimilation techniques and input data used. This causes differences in the model-reproduced atmospheric and surface parameters, their spatio-temporal variations and long-term trends. A typical approach to substantiate the validity and reliability of reanalysis-based estimates involves the comparison of a number of different reanalysis datasets. In this study we compared variation and trends in the sea-level pressure and in the surface wind speed derived from the NCEP/ NCAR dataset with corresponding estimates inferred from ERA5 reanalysis of the European Centre for Medium-Range Weather Forecasts, ECMWF (Hersbach et al., 2020), and from NASA's Modern Era Retrospective Analysis for Research and Applications-2, MERRA2 (Gelaro et al., 2017). Because of a shorter time span of the two latter datasets, a direct comparison of the results was possible only since 1979, i.e., over the time period of about four decades. Along with the NCEP/NCAR reanalysis, ERA5 and MERRA2 datasets were applied to calculate monthly and yearly mean values of zonally averaged sea surface pressure and of the surface wind speed within two latitude belts of $50-60^{\circ} \mathrm{S}$ and $65-85^{\circ} \mathrm{S}$.

Examination of the time series of the two parameters derived from ERA5 and MERRA2 has revealed their much similarity to NCEP/NCAR but also have shown a number of differences. All three datasets have been found to agree well on year-to year changes in the yearly mean sea level pressure and in the surface wind speed in the Antarctic region and, in most cases, on the sign of corresponding trends. Some differences however concerned the estimated trend magnitude. 
Close correlation between time series of the yearly mean values of the two parameters is seen from Fig. 5 presenting estimates for the open ocean area within the $50-60^{\circ} \mathrm{S}$ latitude belt. A decreasing trend in the sea level pressure found in the NCEP/NCAR dataset is supported by MERRA2-based estimates, whereas in ERA5 the sea level pressure trend turned practically neutral. In the last four decades all datasets demonstrated a statistically significant increase of the yearly average surface wind speed with time (Fig. 5b) with the largest trend of $0.028 \mathrm{~m} / \mathrm{s} / \mathrm{yr}$ in NCEP/NCAR and smaller trends in MERRA2 $(0.019 \mathrm{~m} / \mathrm{s} / \mathrm{yr})$ and ERA5 $(0.008 \mathrm{~m} / \mathrm{s} / \mathrm{yr})$. Worth noting is a considerably larger, by $1.5-$ $2 \mathrm{~m} / \mathrm{s}$, zonal mean yearly average wind speed in the MERRA2 dataset as compared to NCEP/NCAR and ERA5.
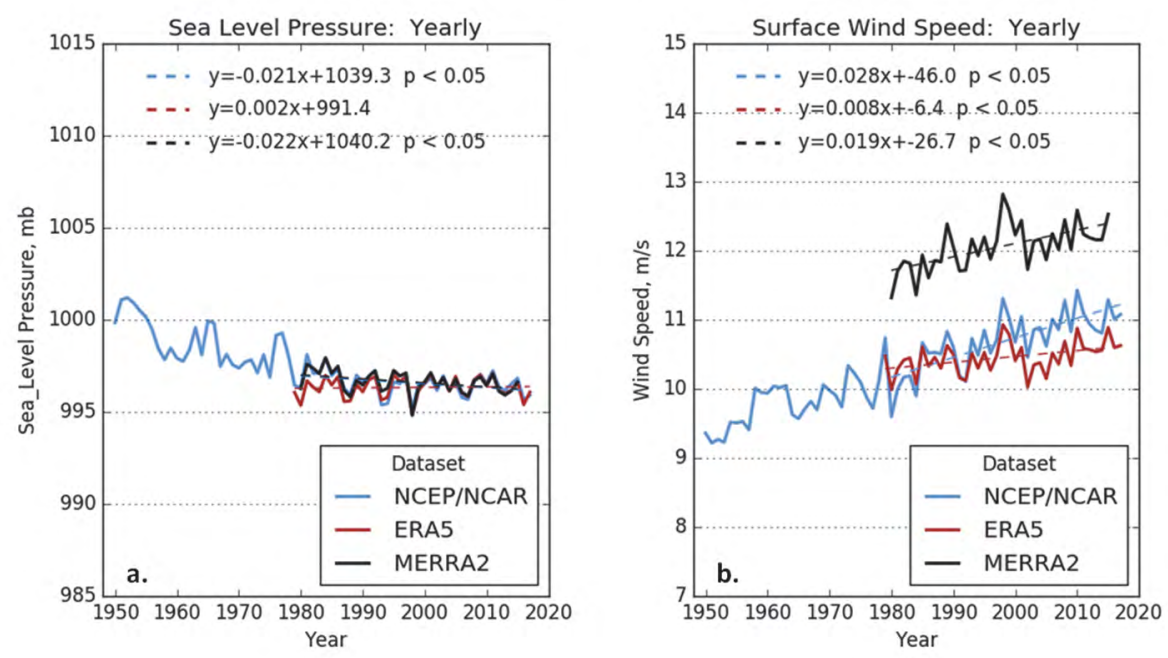

Figure 5. Time series and trends of the yearly mean sea level pressure (a) and of the surface wind speed (b) within $50-60^{\circ} \mathrm{S}$ latitude belt derived from three reanalysis datasets, NCEP/NCAR, ERA5 and MERRA2.

Our further analysis of the three datasets has shown that their agreement on the decreasing trend in the sea level pressure and increasing trend in the wind speed extends further south to the Antarctic coastal and continental areas within the latitude belt of $65-85^{\circ} \mathrm{S}$. Similarly to the open ocean, in this region the NCEP/NCAR dataset demonstrated the largest decrease in the sea level pressure of $-0.094 \mathrm{mb} / \mathrm{yr}$ ( $\mathrm{vs}-0.021 \mathrm{mb} / \mathrm{yr}$ in ERA5 and $-0.043 \mathrm{mb} / \mathrm{yr}$ in MERRA2) and a much larger increase of the wind speed of $0.021 \mathrm{~m} / \mathrm{s} / \mathrm{yr}$ as compared to an almost neutral trend of $0.003 \mathrm{~m} / \mathrm{s} / \mathrm{yr}$ in both ERA5 and MERRA2. Besides the agreement on the sign of the trends, all datasets revealed similar peculiarities in the trend seasonal pattern. This includes a slightly larger decrease in the sea level pressure in the late fall and in winter and generally larger increasing trends in the wind speed over the open ocean during the austral summer and early fall.

A general deepening of the Antarctic Circumpolar Through in the last decades that has been seen in the results of our study agrees well with the results of other Antarctic climate change studies based on the reanalysis data and in situ observations. Turner et al., (2009) identified a gradual decrease of the yearly mean sea level pressure in the 1980s, 
1990s and in the beginning of 2000s in the records of many ground stations in Antarctica. Similar to the results of our analysis of the NCEP/NCAR dataset, the largest trends of up to $0.1 \mathrm{mb} / \mathrm{yr}$ were found in the coastal areas across East Antarctica in austral summer and autumn. Even larger negative pressure trends reaching $0.2 \mathrm{mb} / \mathrm{yr}$ were identified by (Hines et al., 2000) who examined the NCEP reanalysis data in the last five decades of the $20^{\text {th }}$ century. In the latter study however concern has been expressed that these trends may be overestimated. The authors suggest that at least part of the negative trend may be due to a gradual decrease of the positive pressure bias inherent to the sea level pressure reanalysis data in 1950 and most of 1960s. The latter is attributed to the fact that data from only few ground stations in Antarctica were available at that time.

Consistent with the general decrease of the sea level pressure is the observed strengthening of the winds in Antarctica. Evidence for the increasing wind speed was found in various types of environmental records including reanalysis, surface observations and satellite data. Estimates of the magnitude of the trend vary but generally support the results inferred from the NCEP/NCAR dataset. Positive wind speed trends in Antarctica amounting to $0.02-0.04 \mathrm{~m} / \mathrm{s} / \mathrm{yr}$ and thus close to our estimates were established by Young and Ribal (2019) from the analysis of passive and active satellite observations in the microwave. These trends are generally larger than trends in the surface wind speed we saw in the ERA5 and MERRA2 datasets. Increasing wind speed have been reported by Dong et al., (2020) who examined the records at over 50 ground-based stations in Antarctica and six different reanalysis products for the 1980-2018 time period. Trends in the yearly mean wind speed over the whole Antarctic region $\left(60-90^{\circ} \mathrm{S}\right)$ for different reanalysis schemes presented in this study ranged within 0.005 to $0.018 \mathrm{~m} / \mathrm{s} / \mathrm{yr}$. Similar values of the wind speed trend spanning from -0.0026 to $0.013 \mathrm{~m} / \mathrm{s} / \mathrm{yr}$ with largest positive trends during the austral summer have been reported by (Yu et al., 2020). Somewhat larger, generally within $0.02-0.03 \mathrm{~m} / \mathrm{s} / \mathrm{yr}$, estimates of the trends we inferred from the NCEP/NCAR reanalysis, may be explained by the fact that they were obtained over high latitude areas of the Southern Ocean and coastal areas of the Antarctic continent where long term changes in the wind speed in the last decades were the largest.

\section{Conclusion}

Long-term changes in the sea level pressure and in the surface wind speed in the high latitude region of the Southern Hemisphere have been examined using NCEP/NCAR reanalysis data. The study has shown a gradual decrease of the sea level pressure and an increase of the surface wind speed in the last 70 years (1950-2019) both in the polar region of Southern Ocean and in the coastal areas of Antarctica. The estimated trend in the yearly averaged sea level pressure amounted to $-0.058 \mathrm{mb} / \mathrm{yr}$ over the open ocean $\left(50^{\circ} \mathrm{S}-60^{\circ} \mathrm{S}\right)$ and to $-0.148 \mathrm{mb} / \mathrm{yr}$ over the Antarctic continent $\left(65^{\circ} \mathrm{S}-85^{\circ} \mathrm{S}\right)$. Trends in the wind speed over the sea surface and over the continent comprised correspondingly $0.026 \mathrm{~m} / \mathrm{s} / \mathrm{yr}$ and $0.020 \mathrm{~m} / \mathrm{s} / \mathrm{yr}$ with up to the 3-4 times larger values in coastal areas of East Antarctica. Faster decrease of the sea level pressure occurred during the cold period of the year from April to 
August whereas a distinct seasonal pattern in the trends of the surface wind speed with larger values in summer and early fall was identified only over the near-Antarctic open ocean. All trends were found to generally decelerate in the last decade.

We have shown that information on the sign of the trends in the wind speed and pressure in Antarctic inferred from the NCEP/NCAR reanalysis is generally consistent with other reanalyses data and thus may be considered credible. Larger uncertainty is associated with the particular magnitude of the long-term changes. Although trends inferred from the NCEP/NCAR dataset in this study were overall somewhat larger than in other reanalyses, they compare favorably to available in situ and remote sensing observations and therefore appear realistic.

Substantial long-term changes in the sea level pressure and in the surface wind speed, indicate changing atmospheric circulation patterns and, more broadly, changing climate conditions in the polar region of the Southern Hemisphere. These transformations have an immediate impact on the ocean dynamics in the region, as well as on the physics, chemistry and biology of Antarctic waters. A broader-scale analysis incorporating information on other environmental elements as surface temperature, precipitation, surface wind speed components, ice cover may help to improve understanding of the climate change processes in the region. Incorporating a larger scope of reanalysis datasets as well as in situ and remote sensing data should result in more reliable quantitative estimates of the magnitude of the change.

Acknowledgment: The authors are grateful to the reviewers for valuable comments, the consideration of which contributed to the improvement of the article text. The work was carried out within the framework of State Assignment No. 0149-2019-0004.

\section{References}

Anisimov, O.A., D.G. Vaughan, T.V. Callaghan, C. Furgal, H. Marchant, T.D. Prowse, H. Vilhjaisson, and J.E. Walsh. Polar regions (Arctic and Antarctic). Climate Change 2007: Impacts, Adaptation and Vulnerability. Contribution of Working Group II to the Fourth Assessment Report of the Intergovernmental Panel on Climate Change, M.L. Parry, O.F. Canziani, J.P. Palutikof, P.J. van der Linden and C.E. Hanson, Eds., Cambridge: Cambridge University Press, 2007, pp. 653-685.

Comiso, J.C. Variability and Trends in Antarctic Surface Temperatures from In Situ and Satellite Infrared Measurements. Journal of Climate, 2000, Vol. 13, pp. 1674-1696, https://doi.org/10.1175/1520-0442(2000)013.

Dong, X., Y. Wang, S. Hou, M. Ding, B. Yin, and Y. Zhang. Robustness of the Recent Global Atmospheric Reanalyses for Antarctic Near-Surface Wind Speed Climatology. Journal of Climate, 2020, Vol. 33, pp. 4027-4043, https://doi.org/10.1175/JCLI-D-19-0648.1.

Gelaro, R., W. McCarty, M.J. Suárez, R. Todling, A. Molod, L. Takacs, C.A. Randles, A. Darmenov, M.G. Bosilovich, R. Reichle, K. Wargan, L. Coy, R. Cullather, C. Draper, S. Akella, V. Buchard, A. Conaty, A.M. da Silva, W. Gu, G.-K. Kim, R. Koster, R. Lucchesi, D. Merkova, J.E. Nielsen, G. Partyka, S. Pawson, W. Putman, M. Rienecker, S.D. Schubert, M. Sienkiewicz, and B. Zhao. The Modern-Era Retrospective Analysis for Research and Applications, Version 2 (MERRA-2). Journal of Climate, 2017, Vol. 30, pp. 5419-5454. 
Romanova N.A., Romanov P.Yu.

Genthon, C., A. Berne, J. Grazioli, C.D. Alárcon, C.J. Praz, and B. Boudevillain. Precipitation at Dumont d'Urville, Adélie Land, East Antarctica: the APRES3 dataset. Earth System Science, 2018, Vol. 10, pp. 1605-1612.

Hersbach, H., B. Bell, P. Berrisford, S. Hirahara, A. Horányi, J. Muñoz-Sabater, J. Nicolas, C. Peubey, R. Radu, D. Schepers, A. Simmons, C. Soci, S. Abdalla, X. Abellan, G. Balsamo, P. Bechtold, G. Biavati, J. Bidlot, M. Bonavita, G. De Chiara, P. Dahlgren, D. Dee, M. Diamantakis, R. Dragani, J. Flemming, R. Forbes, M. Fuentes, A. Geer, L. Haimberger, S. Healy, R.J. Hogan, E. Hólm, M. Janisková, S. Keeley, P. Laloyaux, P. Lopez, C. Lupu, G. Radnoti, P. de Rosnay, I. Rozum, F. Vamborg, S. Villaume, and J.-N. Thépaut. The ERA5 Global Reanalysis. Quarterly Journal of Royal Meteorological Society, 2020, Vol. 146, pp. 1999-2049, doi: 10.1002/qj.3803.

Hines, K.M., D.H. Bromwich, and G.J. Marshall. Artificial Surface Pressure Trends in the NCEPNCAR Reanalysis over the Southern Ocean and Antarctica. Journal of Climate, 2000, Vol. 13, pp. 3940-3952.

Jones, D.A. and I. Simmonds. A climatology of Southern Hemisphere anticyclones. Climate Dynamics, 1994, Vol. 10, pp. 333-348.

Kalnay, E., M. Kanamitsu, R. Kistler, W. Collins, D. Deaven, L. Gandin, M. Iredell, S. Saha, G. White, J. Woollen, Y. Zhu, M. Chelliah, W. Ebisuzaki, W. Higgins, J. Janowiak, K.C. Mo, C. Ropelewski, J. Wang, A. Leetmaa, R. Reynolds, R. Jenne, and D. Joseph. The NCEP/ NCAR 40-year reanalysis project. Bulletin of American Meteoroloical Society, 1996, Vol. 77, pp. 437-470.

Kanamitsu, M., W. Ebisuzaki, J. Woollen, S.-K. Yang, J.J. Hnilo, M. Fiorino, and G.L. Potter. NCEP-DOE AMIP-II Reanalysis (R-2). Bulletin of American Meteorological Society, 2002, Vol. 83(11), pp. 1631-1644.

Nygård, T., T. Vihma, G. Birnbaum, J. Harmann, J. King, T. Lachlan-Cope, R. Ladkin, C. Lüpkes, and A. Weiss. Validation of eight atmospheric reanalyses in the Antarctic Peninsula region. Quarterly Journal of Royal Meteorological Society, 2016, Vol. 142, pp. 684-692, https://doi.org10.1002/qj.2691.

Romanov, Y.A., N.A. Romanova, and P. Romanov. Distribution of icebergs in the Atlantic and Indian Ocean sectors of the Antarctic region and its possible links with ENSO. Geophysical Research Leters, 2008, Vol. 35(2), L02506, doi: 10.1029/2007/GL031685.

Steig, E., D. Schneider, S. Rutherford, M. Mann, J. Comiso, and D. Shindell. Warming of the Antarctic ice-sheet surface since the 1957 International Geophysical Year. Nature, 2009, Vol. 457, pp. 459-462, https://doi.org/10.1038/nature07669.

Turner, J., S.N. Chenoli, A. abu Samah, G. Marshall, T. Phillips, and A. Orr. Strong wind events in the Antarctic. Journal of Geophyical Research, 2009, Vol. 114, D18103, doi: 10.1029/2008JD011642.

Turner, J. and J. Overland. Contrasting climate change in the two polar regions. Polar Research, 2009, Vol. 28, pp. 146-164, doi: 10.1111/j.1751-8369.2009.00128.x.

Turner, J., J.S. Hosking, G.J. Marshall, T. Phillips, and T. Bracegirdle. Antarctic sea ice increase consistent with intrinsic variability of the Amundsen Sea Low. Climate Dynamics, 2016, Vol. 46, pp. 2391-2402, doi: org/10.1007/s00382-015-2708-9.

Walsh, J. A comparison of Arctic and Antarctic climate change, present and future. Antarctic Science, 2009, Vol. 21(3), pp. 179-188, doi: 10.1017/S0954102009001874.

Wang, Y., D. Zhou, A. Bunde, and S. Havlin. Testing reanalysis data sets in Antarctica: Trends, persistence properties, and trend significance. Journal of Geophysical Research, 2016, Vol. 121, pp. 12839-12855, doi: 10.1002/2016JD024864.

Young, I.R. and A. Ribal. Multiplatform evaluation of global trends in wind speed and wave height. Science, 2019, Vol. 364, pp. 548-52.

$Y u, L$., S. Zhong, and B. Sun. The climatology and trend of surface wind speed over Antarctica and the Southern Ocean and the implication to wind energy application. Atmosphere, 2020, Vol. 11, 108, doi: 10.3390/atmos11010108. 


\title{
УСИЛЕНИЕ ВЕТРА В АНТАРКТИКЕ ПО ДАННЫМ РЕАНАЛИЗА NCEP/NCAR
}

\author{
Романова Н.А. ${ }^{1}$, Романов П.Ю. ${ }^{2}$ \\ ${ }^{1}$ Институт океанологии им. П.П. Ширшова РАН, \\ Россия, 117997, Москва, Нахимовский проспект, d. 36, e-mail: romanova@ocean.ru \\ ${ }^{2}$ NOAA-CREST, City University of New York, New York, NY 10031, USA, \\ e-mail: peter.romanov@noaa.gov \\ Статья поступила в редакцию 21.07.2020, одобрена к печати 15.10.2020.
}

\begin{abstract}
Данные анализа NCEP/NCAR использовались для изучения изменений давления науровне моря и скорости приземного ветра в антарктическом регионе с 1950 по 2019 гг. Целью работы было выявление изменений и количественная оценка долгосрочных тенденций этих двух основных элементы погоды и климата. Были проанализированы временные ряды среднемесячных значений давления на уровне моря и скорости приземного ветра, а также их среднегодовые значения. Исследование показало постепенное снижение давления на уровне моря и постепенное увеличение скорости приземного ветра в высокоширотном районе Южного полушария за последние 70 лет (1950-2019). Наибольшее понижение давления произошло в зоне $65-70^{\circ}$ ю.ш., примерно соответствующей местоположению антарктической циркумполярной ложбины низкого давления (АЦЛ). Рассчитанная величина тренда среднегодового давления изменялась от -0.058 мб/год над открытым океаном к северу от АЦЛ, в диапазоне широт 50-60ำ.ш., до $-0,148$ мб/год над антарктическим континентом, в пределах $65-85^{\circ}$ ю.ш. Тренды зонально-осредненной скорости ветра колебались в пределах $0.020 \mathrm{~m} / \mathrm{c} /$ год и $0.026 \mathrm{~m} / \mathrm{c} /$ год над континентом и над открытым океаном и достигали в 3-4 раза больших значений в прибрежных районах восточной Антарктиды. В сезонной структуре наибольшие изменения обоих параметров произошли в холодный период года с апреля по август. Было обнаружено, что темпы изменения как давления на уровне моря, так и скорости ветра в антарктическом регионе в последнее десятилетие, охватываемое набором данных, в целом замедлились.
\end{abstract}

Ключевые слова: реанализ, изменение климата Антарктики, скорость приземного ветра, давление на уровне моря

Благодарности. Авторы благодарят рецензентов за ценные замечания, учет которых способствовал улучшению текста статьи. Работа выполнена в рамках Госзадания №0149-2019-0004.

\section{Литература}

Anisimov O.A., Vaughan D.G., Callaghan T.V., Furgal C., Marchant H., Prowse T.D., Vilhjaisson H., Walsh J.E. Polar regions (Arctic and Antarctic) // Climate Change 2007: Impacts, Adaptation and Vulnerability. Contribution of Working Group II to the Fourth Assessment Report of the Intergovernmental Panel on Climate Change, Eds.: M.L. Parry, O.F. Canziani, J.P. Palutikof, P.J. van der Linden and C.E. Hanson. Cambridge: Cambridge University Press, 2007. P. 653-685.

Comiso J.C. Variability and Trends in Antarctic Surface Temperatures from In Situ and Satellite Infrared Measurements // Journal of Climate. 2000. Vol. 13. P. 1674-1696. https://doi.org/10.1175/1520-0442(2000)013.

Dong X., Wang Y., Hou S., Ding M., Yin B., Zhang Y. Robustness of the Recent Global Atmospheric Reanalyses for Antarctic Near-Surface Wind Speed Climatology // Journal of Climate. 2020. Vol. 33. P. 4027-4043. https://doi.org/10.1175/JCLI-D-19-0648.1. 
Gelaro R., McCarty W., Suárez M.J., Todling R., Molod A., Takacs L., Randles C.A., Darmenov A., Bosilovich M.G., Reichle R., Wargan K., Coy L., Cullather R., Draper C., Akella S., Buchard V., Conaty A., da Silva A.M., Gu W., Kim G.-K., Koster R., Lucchesi R., Merkova D., Nielsen J.E., Partyka G., Pawson S., Putman W., Rienecker M., Schubert S.D., Sienkiewicz M., Zhao B. The Modern-Era Retrospective Analysis for Research and Applications, Version 2 (MERRA-2) // Journal of Climate. 2017. Vol. 30. P. 5419-5454.

Genthon C., Berne A., Grazioli J., Alárcon C.D., Praz C.J., Boudevillain B. Precipitation at Dumont d'Urville, Adélie Land, East Antarctica: theAPRES3 dataset // Earth System Science. 2018. Vol. 10. P. 1605-1612.

Hersbach H., Bell B., Berrisford P., Hirahara S., Horányi A., Muñoz-Sabater J., Nicolas J., Peubey C., Radu R., Schepers D., Simmons A., Soci C., Abdalla S., Abellan X., Balsamo G., Bechtold P., Biavati G., Bidlot J., Bonavita M., De Chiara G., Dahlgren P., Dee D., Diamantakis M., Dragani R., Flemming J., Forbes R., Fuentes M., Geer A., Haimberger L., Healy S., Hogan R.J., Hólm E., Janisková M., Keeley S., Laloyaux P., Lopez P., Lupu C., Radnoti G., de Rosnay P., Rozum I., Vamborg F., Villaume S., Thépaut J.-N. The ERA5 Global Reanalysis // Quarterly Journal of Royal Meteorological Society. 2020. Vol. 146. P. 1999-2049. DOI: 10.1002/qj.3803.

Hines K.M., Bromwich D.H., Marshall G.J. Artificial Surface Pressure Trends in the NCEPNCAR Reanalysis over the Southern Ocean and Antarctica // Journal of Climate. 2000. Vol. 13. P. 3940-3952.

Jones D.A., Simmonds I. A climatology of Southern Hemisphere anticyclones // Climate Dynamics. 1994. Vol. 10. P. 333-348.

Kalnay E., Kanamitsu M., Kistler R., Collins W., Deaven D., Gandin L., Iredell M., Saha S., White G., Woollen J., Zhu Y., Chelliah M., Ebisuzaki W., Higgins W., JanowiakJ., Mo K. C., Ropelewski C., Wang J., Leetmaa A., Reynolds R., Jenne R., Joseph D. The NCEP/NCAR 40-year reanalysis project // Bulletin of American Meteorological Society. 1996. Vol. 77. P. 437-470.

Kanamitsu M., Ebisuzaki W., Woollen J., Yang S.-K., Hnilo J.J., Fiorino M., Potter G.L. NCEPDOE AMIP-II Reanalysis (R-2) // Bulletin of American Meteorological Society. 2002. Vol. 83(11). P. 1631-1644.

Nygård T., Vihma T., Birnbaum G., Harmann J., KingJ., Lachlan-Cope, T., Ladkin R., Lüpkes C., Weiss A. Validation of eight atmospheric reanalyses in the Antarctic Peninsula region // Quarterly Journal of Royal Meteorological Society. 2016. Vol. 142. P. 684-692. https://doi.org10.1002/qj.2691.

Romanov Y.A., Romanova N.A, Romanov P. Distribution of icebergs in the Atlantic and Indian ocean sectors of the Antarctic region and its possible links with ENSO // Geophysical Research Letters. 2008. Vol. 35(2). L02506. DOI: 10.1029/2007/GL031685.

Steig E., Schneider D., Rutherford S., Mann M., Comiso J., Shindell D. Warming of the Antarctic ice-sheet surface since the 1957 International Geophysical Year // Nature. 2009. Vol. 457. P. 459-462. https://doi.org/10.1038/nature07669.

Turner J., Chenoli S.N., abu Samah A., Marshall G., Phillips T., Orr A. Strong wind events in the Antarctic // Journal of Geophysical Research. 2009. Vol. 114. D18103. DOI: $10.1029 / 2008 J D 011642$.

Turner J., Overland J. Contrasting climate change in the two polar regions // Polar Research. 2009. Vol. 28. P. 146-164. DOI: 10.1111/j.1751-8369.2009.00128.x.

Turner J., Hosking J.S., Marshall G.J., Phillips T., Bracegirdle T. Antarctic sea ice increase consistent with intrinsic variability of the Amundsen Sea Low // Climate Dynamics. 2016. Vol. 46. P. 2391-2402. https://doi.org/10.1007/s00382-015-2708-9.

Walsh J. A comparison of Arctic and Antarctic climate change, present and future // Antarctic Science. 2009. Vol. 21(3). P. 179-188. DOI: 10.1017/S0954102009001874.

Wang Y., Zhou D., Bunde A., Havlin S. Testing reanalysis data sets in Antarctica: Trends, persistence properties, and trend significance // Journal of Geophysical Research. 2016. Vol. 121. P. 12839-12855. DOI: 10.1002/2016JD024864.

Young I.R., Ribal A. Multiplatform evaluation of global trends in wind speed and wave height // Science. 2019. Vol. 364. P. 548-552.

Yu L., Zhong S., Sun B. The climatology and trend of surface wind speed over Antarctica and the Southern Ocean and the implication to wind energy application // Atmosphere. 2020. Vol. 11. 108. DOI: 10.3390/atmos11010108. 